\title{
CHARACTERISTICS OF PEAT PROPERTIES FROM EXTRACTED PEATLANDS IN THE CONTEXT OF SUSTAINABLE MANAGEMENT
}

\author{
Izstrādāto purvu kūdras īpašību raksturojums \\ ilgtspējīgas apsaimniekošanas kontekstā
}

\author{
Reinis Bitenieks, Laimdota Kalniṇa, Ingrīda Krīgere, Jānis Dreimanis \\ University of Latvia, Faculty of Geography and Earth Sciences \\ bitenieks.reinis@gmail.com
}

\begin{abstract}
The degradation level and re-cultivation possibilities of extracted peat fields have usually been evaluated using data from vegetation studies, and partly from hydrological measurements. Very little attention has been paid to the remaining peat layer properties; however, this is important for the planning and choice of scenario for re-cultivation. The aim of this study has been to investigate the properties of the remaining peat section with special attention to the top layer. This research project included the following laboratory methods: loss - on ignition method, $\mathrm{pH}$, degree of peat decomposition botanical composition and natural peat density analysis. The results of this study point to those peat properties that are changing due to extraction processes. The obtained results suggest that peat properties in the studied affected peatlands vary differently. The top layers of the peat section have a higher natural density and increased amount of mineral matter. The main changes observed were in the peat natural moisture, $\mathrm{pH}$, mineral content, degradation rates, and ash content, which in the extracted peat field were associated with hydrological regime modification.
\end{abstract}

Keywords: deposit composition, natural density, botanical composition, degree of decomposition, $p H$

\section{Introduction}

Peat is the natural resource of Latvia whose potential for use is important for the development of the country, but which is not yet fully understood and has not achieved its full economic potential. It is also necessary to identify which recultivation measures should be promoted as being more efficient, economical and more bio-diversity friendly with the least possible negative impact on climate change.

When the peatland is being prepared for peat cutting, the vegetation is removed in the planned extraction area and the hydrological regime is changed by the drainage system. The part of mineral matter increases in the content of peat, especially at the top of the section with resultant peat compaction. Upon completion or discontinuation of peat extraction, the remaining top layer of peat differs by the degree of its natural density, as well as other peat properties, including the proportion of mineral parts in the peat composition and the degree of decomposition.

By exploring and studying the degraded peat fields, the focus, so far, has been on the analysis of peatland vegetation, most often assessing its re-generation potential. In order to select the most suitable type of re-cultivation, it is necessary to carry out research and to evaluate the state of each specific peat field and the properties of the remaining layer of peat (Lācis 2010). Several LIFE projects have been implemented in Latvia, as a result of which restoration of the hydrological regime of the peatland has 
been carried out, eliminating the consequences of the reclamation by man and facilitating the improvement and restoration of the mire habitat status (Pakalne 2013).

For planning management and re-cultivation of the peatlands, it is necessary to determine the properties of the remaining peat layers, which have previously rarely been studied in Latvia. It was decided to research the pilot areas of the LIFE REstore project at the Lielsalas, Drabinu, Kaigu and Kemeri peatland fields because there are planned or already undergoing re-cultivation processes. For peat extraction sites where recultivation is going to be started, the project implementers need to be informed about the best form of re-cultivation. It is necessary to develop a methodology and action plan for the full evaluation of territories from the geological, quality, economic and biological aspects of the site, thus gaining confidence in the purpose and type of further use of each territory.

\section{Materials and Methods}

During the elaboration of this research work theoretical studies and practical aspects of the research were carried out. Research consisted of several expeditions, territory survey and field work in the peat fields of the Lielsalas, Kaigu, Drabinu, and Kemeri peatland (Figure 1). Collected deposit samples were taken to the laboratory for processing and analyses. During the cameral work, information collected during fieldwork and the results of laboratory analyses were processed and visualized. The data obtained at the end of the study were analysed, interpreted and compared.

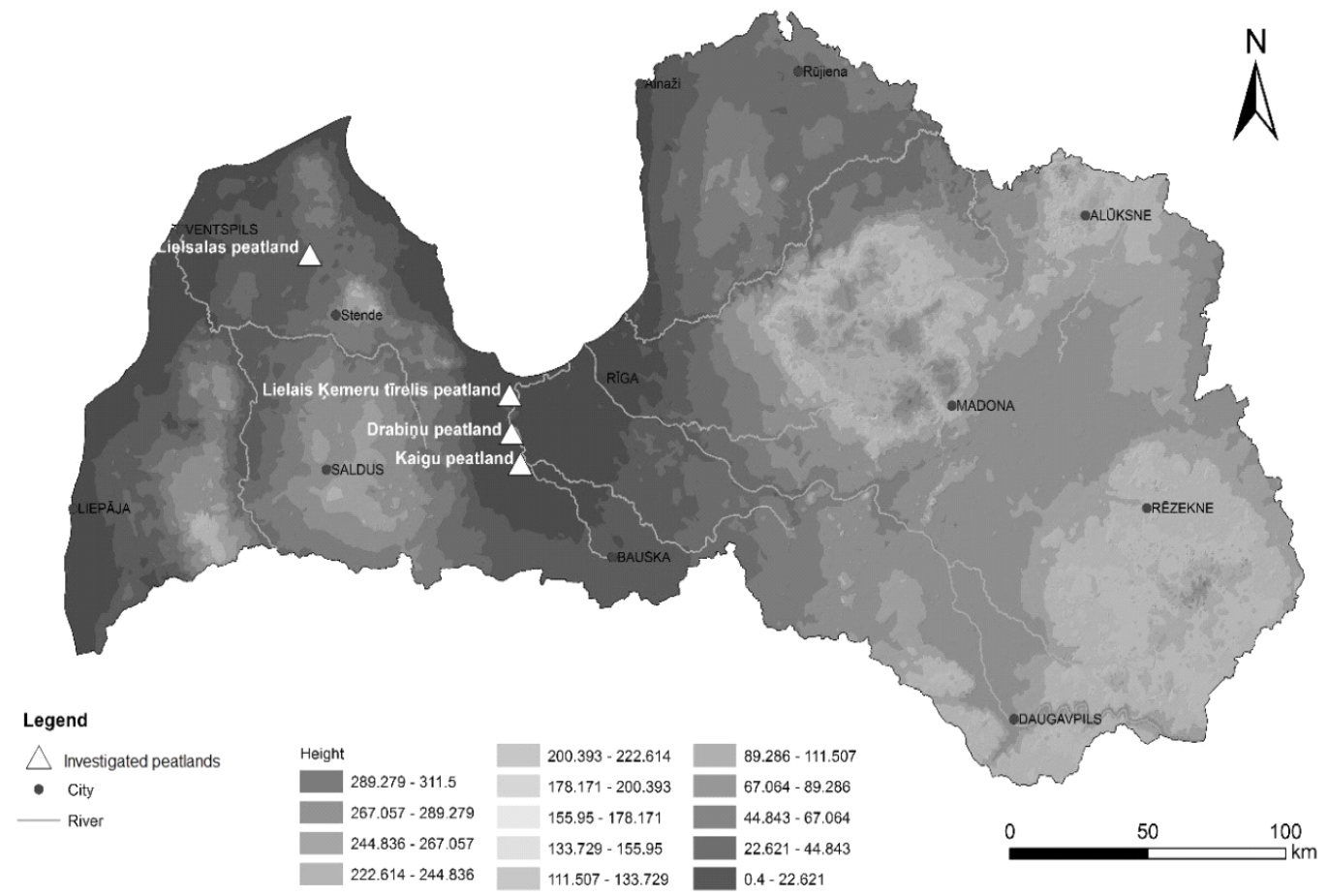

Figure 1. Location of the investigated peatlands (authors' figure)

Field studies were conducted and deposit samples were collected in three expeditions on 29 September, 13 October and 28 October 2016. In each of these peat 
fields, at the beginning, soundings were made to find the most suitable place for the geological coring and collecting of deposit samples. Geological coring was performed by using a soft sediment core with a $0.5 \mathrm{~m}$ long chamber. Nine cores were performed during the field work and deposit monoliths were obtained. Deposit monoliths were required to perform a complete analysis in the laboratory including the questions of loss on ignition, magnetic sensitivity, $\mathrm{pH}$, degree of peat decomposition and botanical composition analysis.

Loss on ignition analysis is used to determine the percentage of organic matter accumulated in peat, mineral matter and carbonates deposited in the sediment in the form of calcium carbonates or other sediment samples (Heiri et al. 2001). This method is based on successive sample heating at $550^{\circ} \mathrm{C}$ and $900^{\circ} \mathrm{C}$ in special muffle furnaces. In addition to the determination of organic matter, mineral content and carbonates, formulas are used to calculate ash, peat density and dry matter.

The natural density of peat is observed as the mass (air sample) and undisturbed volume ratios of the monolith sample. Peat air mass was obtained by at least 12 hours drying at $105^{\circ} \mathrm{C}$. The accuracy of the results may be affected by the deformation of the peat sample and disruption of the natural structure during transportation (McKeague 1976; ASTM-D4531-86 2002).

The $\mathrm{pH}$ of the peat is measured in a solution with a 1:5 ratio of sample to reagent. The solution is prepared from 1 part peat sample and 5 parts de-ionized water (ISO 10390 2005).

Peat samples were removed at different intervals (taking into account loss on ignition results of the analysis) at the extracted peat fields where the most significant changes were observed in the amounts of mineral matter.

The method of peat decomposition degree is based on the area of the unstructured part of the peat (humus) identification of the peat preparation and its expression as a percentage of the total preparation square. The field determination is performed in a binocular microscope with magnification by 56-140 times.

Peat botanical composition is determined on the basis of the macroscopic and microscopic features of the peat and the identification of the main plants of peat composition. This is important for peat type determination. Botanical composition of peat allows for an understanding of the bog vegetation dynamics during peatland development over time. The composition of the peat-forming plants together with data on the degree of peat decomposition characterises peat properties, as well as helps reconstruct paleo-ecological conditions during the peat accumulation.

\section{Results}

\section{Results of loss on ignition analysis}

Significant changes in the sediment composition of all investigated cuts are due to a significant increase in the percentage of minerals in the lower and upper part of the deposit sections, indicating anthropogenic effects. The increase in minerals in the upper part of the incisions indicates the effects of wind and mineralization of the soil. 
The diagrams of loss on ignition analysis results are divided into zones (I - IV) (Figure 2).

Organic substances dominate in all sections of the Lielsala peatland. The increase of the mineral content is observed in the base of the incisions and decreases upwards. The carbonate content is small (not more than 1\%) in all sections of the Lielsala peatland, indicating that the minerals of the carbonate content have not flushed.

The remaining layer of the Lielsala peatland part and the increase in the amount of minerals in the peat composition may be explained by peat sowing and compaction as a result of susceptibility, which indicates the significant impact of human activity.

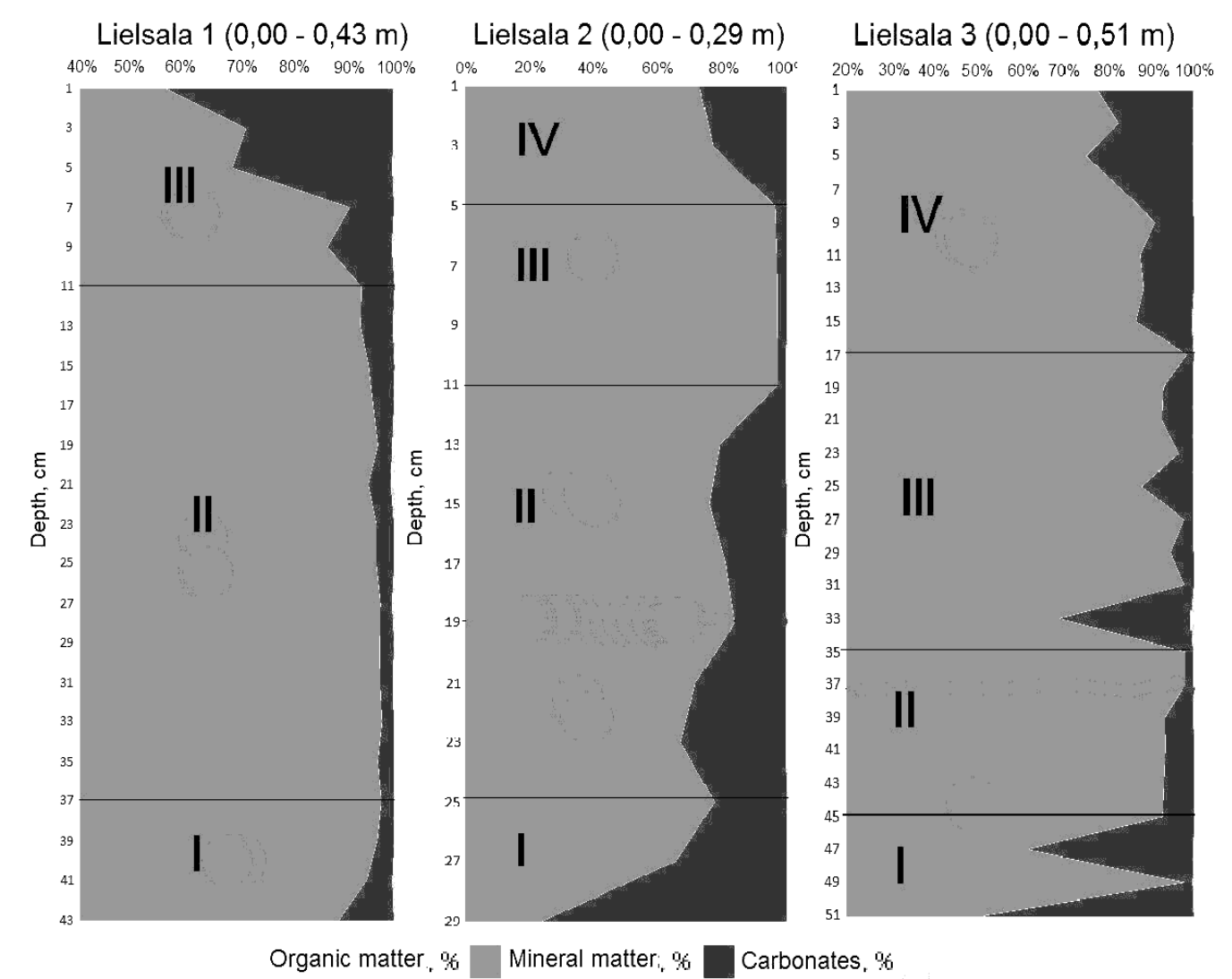

Figure 2. Results of loss on ignition analysis from different sites of the Lielsala peatland (authors' figure)

\section{Peat decomposition degree and botanical composition analysis}

The remaining peat layer in different extracted peat fields consists of various peat types with different degrees of decomposition, which can be explained by the fact that peat formation started in different peatland areas at different times and under different environmental conditions.

The obtained results of this study allow us to conclude that the remaining peat layer in the excavated fields of the Kaigu peatland consists of all three consecutive types of peat: fen, transitional and raised bog type. All of these are well decomposed by more than $40 \%$ apart from the upper layer of the Sphagnum, whose decomposition degree decreases to $32 \%$, but it is still well-decomposed peat. Such a degree of 
decomposition is not characteristic for raised bog peat types and suggests that peat cutting and drainage affects peat properties.

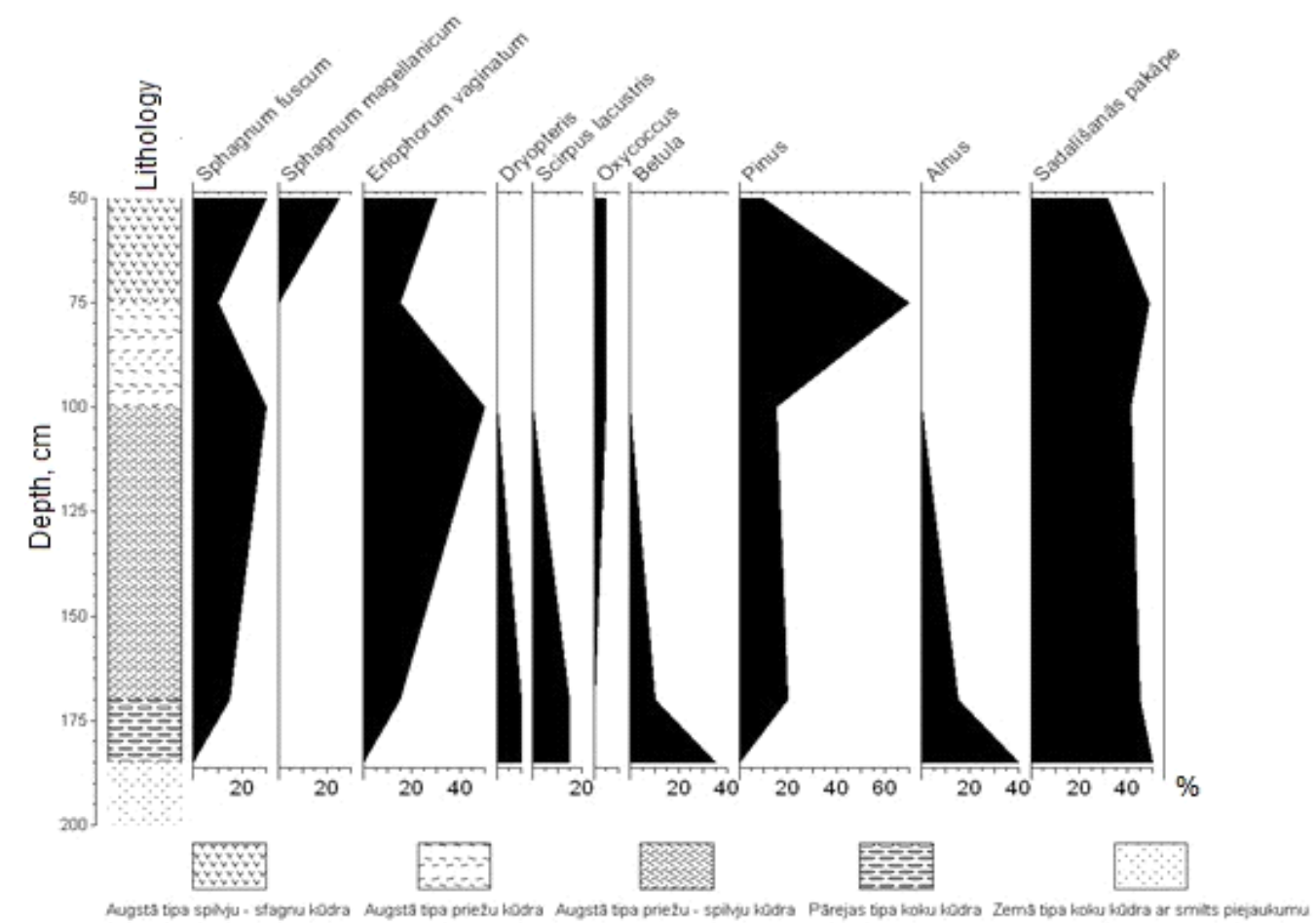

Figure 3. Results of botanical composition analysis from the Kaigu peatland (authors' figure)

The analysis of the obtained results allows us to conclude that the remaining peat layer in the fields of the extracted part of the Kaigu Peatland consists of peat represented by all three peat types: fen, transitional and raised bog peat. All of these are well-decomposed by over $40 \%$, except, for the top layer of the cotton grassSphagnum peat itself, with a decomposition degree of $32 \%$.

\section{Results of pH analysis}

The results of the $\mathrm{pH}$ analysis from the Drabinas peatland peat section show that the lower depth interval $(2.0-1.60 \mathrm{~m})$ has the highest $\mathrm{pH}$ values, possibly related to the significant amount of mineral matter, forming about $30 \%$ ash in the peat composition.

In the upward direction $(1.60-0.80 \mathrm{~m})$, the $\mathrm{pH}$ values gradually decrease from 5.7 to 4.3 , which can be related to the natural raised bog/transitional mire environment and is supported by raised bog type Sphagnum fuscum peat in this depth.

The upper part of the peat section is characterised by gradual increase in $\mathrm{pH}$ values, while peat forming vegetation composition in this depth interval indicates plant feeding with atmospheric precipitation and suggests an acid environment. Taking in account this fact and obtained $\mathrm{pH}$ results it can be determined that the upper peat layer is affected by drainage and surface waters. 


\section{Results of natural peat density analysis}

The natural density of peat is an important characteristic of peat. After that, it is possible to determine the effect of bog drainage on peat compaction and density, which is expressed as the volume of unmodified and immature monolithic sample volume and completely dry, dried sample (Krūmiņš et al. 2012).

Previous studies have shown that peat density in natural bogs increases with depth as well as a higher degree of decomposition and increase in the percentage of mineral matter content in peat (Šnore 2013). The density of remaining peat layers differs from the natural bog's peat density. Normally, the density increases at the bottom of the peat layer due the weight of the peat, but in extracted peatlands density values are higher, due to drainage.

After analysis of the remaining peat layers, the trends of peat density changes differ from natural bogs. The main difference is the increase in the density of the peat in the upper part of the sections, where it is larger than in the base of section. In the increment, the Lielsala 2 density increases significantly in the range of $0.25-0.13 \mathrm{~m}$. This can be explained by an increase in the degree of peat decomposition, which reaches $35 \%$ in this range.

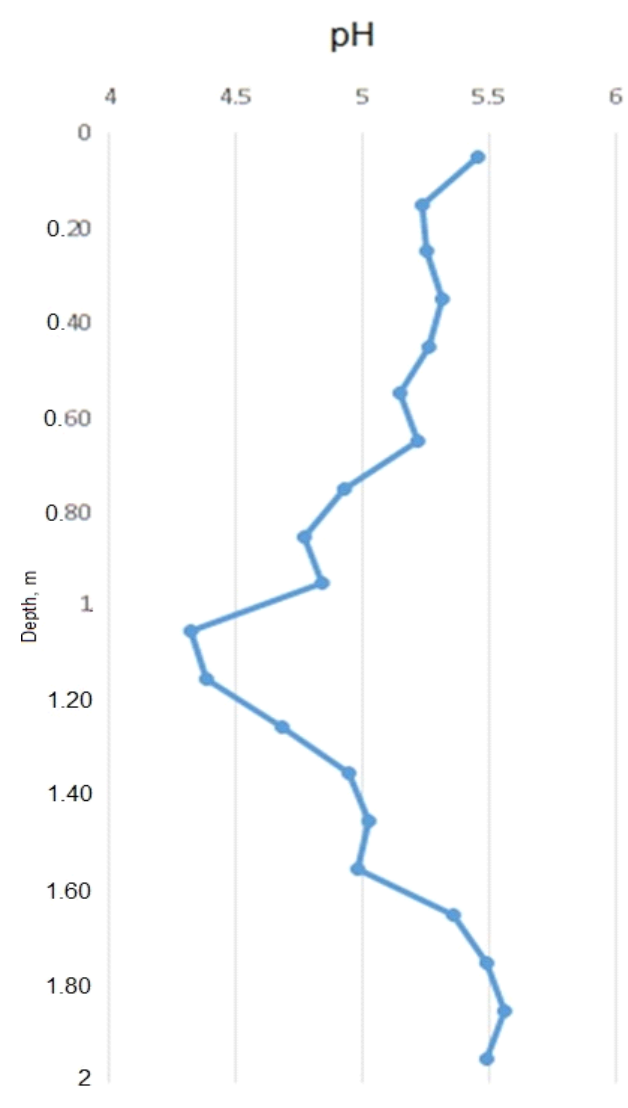

Figure 4. Results of pH analysis from the Drabinu peatland (authors' figure)

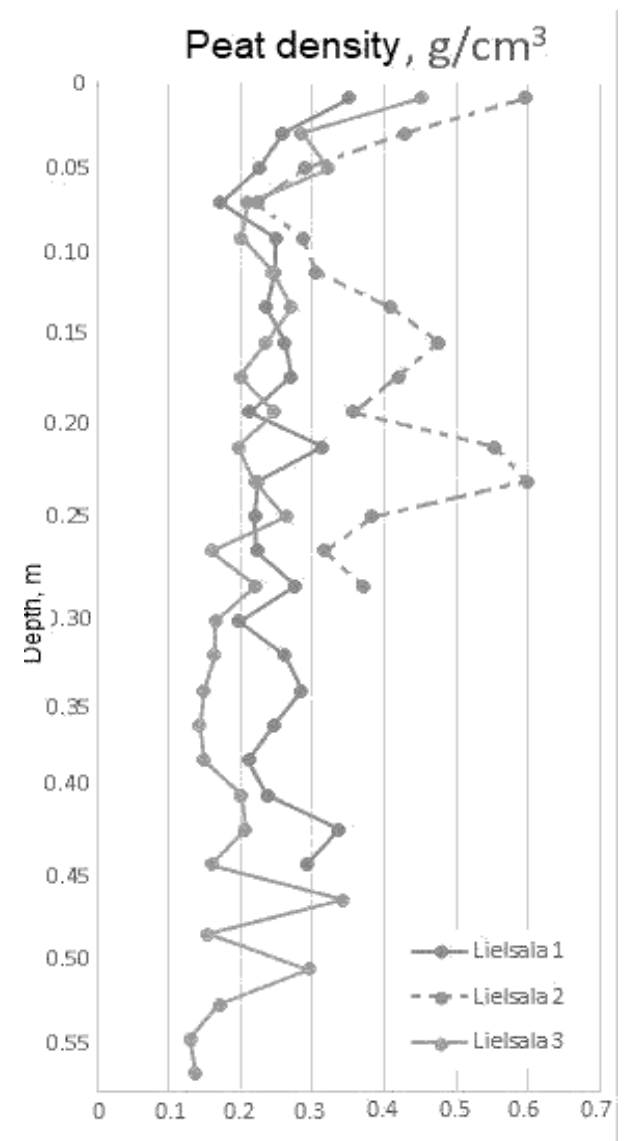

Figure 5. Results of natural peat density analysis from the Lielsalas peatland (authors' figure) 


\section{Conclusion}

- The density of the remaining peat layers differs from the natural peat bogs. Usually it increases in the upper part of the deposit section compared to the base of the section.

- Factors that affect natural density indicators in the studied areas are the degree of decomposition of peat, $\mathrm{pH}$, and the amount of mineral part in deposit composition and the change of peatland hydrological regime.

- Significant changes in the sediment composition in all investigated peat sections are due to a significant increase in the percentage of mineral matter in the lower and upper parts of the sections that are characteristic of the extracted peatlands.

- The characteristics of peat from the peatlands of Lielsala, Drabinu, Kaige and Lielais Kemeru tîrelis were mainly influenced by changes in the hydrological regime caused by the drainage of peat fields.

\section{Kopsavilkums}

Līdz šim galvenā uzmanība degradēto kūdras lauku apzināšanā un izpētē tiek veltīta purvu veǵetācijas analīzei, galvenokārt novērtējot tās atjaunošanās iespējas. Pētijuma mērkis ir raksturot četru izstrādāto purvu - Lielsalas, Kaigu, Drabiṇu un Ķemeru tîreḷa kūdras slāṇu īpašības, izmantojot lauka darbu un laboratorijas pētījumu metodes: karsēšanas zudumu analīzi $(L O I), \mathrm{pH}$, kūdras botāniskā sastāva un sadalī̌̌anās pakāpes analīzi un kūdras dabīgā blīvuma analīzi.

Pētījumā iegūtie rezultāti norāda uz to, ka galvenās kūdras īpašību pārmaiņas cilvēka darbības ietekmētajos purvos ir kūdras dabīgā mitruma samazināšanās, blīvuma palielināšanās, pH un minerālvielu daudzuma palielināšanās, kas saistāma ar kūdras lauka hidrolog̣iskā režīma pārmaiṇām nosusināšanas rezultātā.

\section{References}

ASTM International [ASTM]. (2002). Standard test methods for bulk density of peat and peat products. ASTM-D4531-86 2002.

Bitenieks, R. (2017). Izstrādāto purvu kūdras slāṇu īpašību raksturojums. Rīga: Latvijas Universitāte, Bakalaura darbs.

Heiri, O., Lotter, A.F., Lemcke, G. (2001). Loss on ignition as a method for estimating organic and carbonate content in sediments: reproducibility and comparability of results. Journal of Paleolimnology, 25, 101-110.

International Organization for Standardization. (2005). Soil quality - Determination of $\mathrm{pH}$. Chemical characteristics of soils. ISO 103902005.

Krūmiņš, J., Silamiķele, I., Purmalis, O, Stankeviča, K., Kušķe, E., Pujāte, A., Ozola, I., Ceriņa, A., Rūtiņa L., Stivriņš, N. (2012). Kūdras un sapropeḷa pētījumu metodes. Rīga: LU Akadēmiskais apgāds, 132.

Lācis, A. (2010). Purvu apzināšana un izpēte Latvijā, pielietotās metodes un sasniegtie rezultāti. Latvijas Universitātes raksti, Zemes un vides zinātnes, 752, 106-115.

Pakalne, M., Strazdiņa, L. (2013). Augsto purvu apsaimniekošana biologisiskās daudzveidības saglabāšanai Latvijā. Rīga: Hansa Print Riga.

Šnore, A. (2013). Purvi un kūdra. Küdras ieguve. Rīga: Nordik. 367. 